\title{
Oxidative Nanopatterning of Titanium Surfaces Promotes Production and Extracellular Accumulation of Osteopontin
}

\author{
Renan de Barros e Lima BUENO ${ }^{1}$ \\ Patricia ADACHI ${ }^{1}$ \\ Larissa Moreira Spinola de CASTRO-RAUCCI ${ }^{1}$ \\ Adalberto Luiz ROSA ${ }^{1}$ \\ Antonio NANCI ${ }^{2}$ \\ Paulo Tambasco de OLIVEIRA ${ }^{1}$ \\ ${ }^{1}$ Ribeirão Preto Dental School, USP - University of São Paulo, Ribeirão Preto, SP, Brazil \\ ${ }^{2}$ Laboratory for the Study of Calcified Tissues and Biomaterials, Faculté de Médecine Dentaire, \\ Université de Montréal, Montréal, Québec, Canada
}

\begin{abstract}
The bone-biomaterial interface has been characterized by layers of afibrillar extracellular matrix (ECM) enriched in non collagenous proteins, including osteopontin (OPN), a multifunctional protein that in bone controls cell adhesion and ECM mineralization. Physical and chemical aspects of biomaterial surfaces have been demonstrated to affect cell-ECM-substrate interactions. The present paper described the ability of oxidative nanopatterning of titanium (Ti) surfaces to control extracellular OPN deposition in vitro. Ti discs were chemically treated by a mixture of $\mathrm{H}_{2} \mathrm{SO}_{4} / \mathrm{H}_{2} \mathrm{O}_{2}$ for either $30 \mathrm{~min}$ [Nano(30') Ti] or $4 \mathrm{~h}$ [Nano(4h) Ti]. Non-etched Ti discs were used as control. Primary osteogenic cells derived from newborn rat calvarial bone were plated on control and etched Ti and grown under osteogenic conditions up to 7 days. High resolution scanning electron microscopy revealed that treated Ti discs exhibited a nanoporous surface and that areas of larger nanopits were noticed only for Nano(4h) Ti. Large extracellular OPN accumulation were detectable only for Nano(4h) Ti, which was associated with OPN-positive cells with typical aspects of migrating cells. At day 3 , quantitative results in terms of areas of OPN labeling were as follows: Nano(4h) Ti $>$ Nano(30') Ti $>$ Control Ti. In conclusion, chemically nanostructured Ti surfaces may support the enhancement of endogenous extracellular OPN deposition by osteogenic cells in vitro depending on the etching time, a finding that should be taken into consideration in strategies to biofunctionalize implant surfaces with molecules with cell adhesion capacity.
\end{abstract}

Key Words: osteopontin, titanium, nanotopography, cell culture, osteoblast.

\section{INTRODUCTION}

Osteopontin (OPN) is a multifunctional, matricellular protein of the SIBLING (small integrinbinding ligand, N-linked glycoprotein) family, which is expressed by many tissues and cell types, either under physiological or pathological conditions (reviewed in 1-3). In bone, OPN is expressed by osteoblastic cells and osteoclasts and have been associated with the control of extracellular matrix (ECM) mineralization/ mineral crystal growth, osteoblastic cell adhesion and proliferation, and osteoclast function $(4,5)$. The unique conserved regions of the OPN molecule, i.e. RGD and
non-RGD domains, thrombin cleavage site, polyaspartic acid sequence, and serine/threonine phosphorylation sites, can account for the diverse functions attributed to this protein (reviewed in 3). Ultrastructural immunolabeling has revealed that in addition to be distributed throughout bone mineralized matrix, OPN preferentially accumulates at bone interfaces, including cement lines, laminae limitantes, margins of surgically created bony defects, and at bone-biomaterial interface (6).

In the field of implantology, biomaterial surface structuring at the nanoscale and its functionalization represent the next generation of implant devices (7). Strategies to functionalize nanostructured metallic

Correspondence: Prof. Dr. Paulo Tambasco de Oliveira, Departamento de Morfologia, Estomatologia e Fisiologia, Faculdade de Odontologia de Ribeirão Preto, USP, Avenida do Café, S/N, 14040-904 Ribeirão Preto, SP, Brasil. Tel: +55-16-3602-3978. Fax: +55-16-3633-0999. e-mail: tambasco@usp.br 
implant surfaces with bioactive molecules include proteins and peptides that promote osteoblastic cell adhesion and function (8-12). Among these, the use of recombinant matricellular proteins, bone sialoprotein (BSP) and OPN, have been considered to be promising surface coatings aiming to promote cell adhesion and tissue repair at the interfacial region $(13,14)$. Importantly, in order to optimize biofunctionalization it should be first taken into consideration the impact that nanotopographical features per se would exert on protein synthesis and secretion by cells directly interacting with the material surface. Indeed, nanostructuring of titanium (Ti) surfaces with a simple chemical treatment using a mixture of $\mathrm{H}_{2} \mathrm{SO}_{4} / \mathrm{H}_{2} \mathrm{O}_{2}$ stimulates the early extracellular OPN accumulation by osteogenic cells that precedes an enhancement in matrix mineralization (15-17). In this context, such aggregates of endogenous OPN would advantageously act as a natural surface coating.

Considering that changes in nanoscale surface features may have an impact in protein adsorption $(7,8,18)$ and that chemically produced nanotopography can be tuned by altering the relative proportions of acid/base and oxidant, temperature and time of etching (19), the present paper aimed to evaluate the effects of two different Ti surface nanotopographies on the early expression of OPN by osteogenic cells in vitro.

\section{MATERIAL AND METHODS}

\section{Titanium Samples and Surface Characterization}

Commercially pure, grade $2 \mathrm{Ti}$ discs, $13 \mathrm{~mm}$ in diameter and $2 \mathrm{~mm}$ thick, were polished with silicon carbide abrasive papers (320 and 600 grit), cleaned by sonication, rinsed with toluene, and treated with a mixture consisting of equal volumes of $10 \mathrm{~N} \mathrm{H}_{2} \mathrm{SO}_{4}$ and $30 \%$ aqueous $\mathrm{H}_{2} \mathrm{O}_{2}$ for either $30 \mathrm{~min}$ or $4 \mathrm{~h}$ [hereafter referred to as Nano(30') Ti and Nano(4h) $\mathrm{Ti}$, respectively] at room temperature (RT) under continuous agitation. The cleaned, oxidized samples were thoroughly rinsed with $\mathrm{dH}_{2} \mathrm{O}$, autoclaved, and air-dried. Control, untreated discs (Control Ti) were similarly cleaned and also autoclaved $(16,17)$. The surface of randomly selected treated and untreated discs was examined using a JEOL JSM-7400F field emission scanning electron microscope (SEM) (JEOL, Tokyo, Japan) operated at 1-2 kV. The acquired digital images were processed using Adobe Photoshop software (Adobe Systems Inc., San Jose, CA, USA).

\section{Cell Isolation and Primary Culture of Osteogenic Cells}

Osteogenic cells were isolated by sequential trypsin/collagenase digestion of calvarial bone from newborn (2-4 days old) Wistar rats, as previously described $(16,17,20,21)$. All animal procedures were in accordance with guidelines of the Animal Research Ethics Committee of the University of São Paulo, Brazil. Cells were plated on Ti discs placed in 24-well polystyrene plates at a cell density of 20,000 cells/well. The plated cells were grown for periods up to 7 days using Gibco $\alpha$-Minimum Essential Medium with L-glutamine (Invitrogen, Carlsbad, CA, USA) supplemented with $10 \%$ fetal bovine serum (Invitrogen), $7 \mathrm{mM}$ $\beta$-glycerophosphate (Sigma, St. Louis, MO, USA), $5 \mathrm{mg} /$ $\mathrm{mL}$ ascorbic acid (Sigma), and $50 \mathrm{mg} / \mathrm{mL}$ gentamicin (Invitrogen) at $37^{\circ} \mathrm{C}$ in a humidified atmosphere with $5 \% \mathrm{CO}_{2}$. The culture medium was changed at days 3 and 5. The progression of cultures was examined by phase contrast microscopy (Axiovert 25; Carl Zeiss, Jena, Germany) of cells grown on polystyrene.

\section{Immunolocalization of OPN}

At days 1, 3, and 7, cells were fixed for 10 $\min$ at RT using $4 \%$ paraformaldehyde in $0.1 \mathrm{M}$ phosphate buffer (PB), pH 7.2. After washing in $\mathrm{PB}$, they were processed for immunofluorescence labeling $(16,17,20,21)$. Cells were permeabilized with $0.5 \%$ Triton X-100 (Acros Organics, Geel, Belgium) in PB for $10 \mathrm{~min}$ followed by blocking with $5 \%$ skimmed milk in PB for 30 min. Primary monoclonal antibody to OPN was used (MPIIIB10-1, 1:800; Developmental Studies Hybridoma Bank, Iowa City, IA, USA), followed by a mixture of Alexa Fluor 594 (red fluorescence) conjugated goat anti-mouse secondary antibody (1:200, Molecular Probes; Invitrogen) and Alexa Fluor 488 (green fluorescence)-conjugated phalloidin (1:200, Molecular Probes; Invitrogen), used to visualize the actin cytoskeleton and the cell outlines. Additionally, some samples were also labeled with BSP antibody (WVID19C5, 1:200, Developmental Studies Hybridoma Bank). All incubations were performed in a humidified environment for $60 \mathrm{~min}$ at RT. Between each incubation step, the samples were washed 3 times ( 5 min each) in PB. Before mounting for microscope observation, samples were briefly washed with deionized water $\left(\mathrm{dH}_{2} \mathrm{O}\right)$ and cell nuclei stained with $300 \mathrm{nMDAPI}$ (Molecular Probes; Invitrogen) for $5 \mathrm{~min}$. Ti discs were mounted face up 
on glass slides, while a Fisherbrand $12 \mathrm{~mm}$-round glass coverslip (Fisher Scientific, Pittsburgh, PA, USA) was mounted with an antifade kit (Vectashield; Vector Labs, Burlingame, CA, USA) on the surface containing cells. The samples were then examined under epifluorescence using a Leica DMLB light microscope (Leica, Bensheim, Germany), outfitted with a Leica DC 300F digital camera. The acquired digital images were processed with Adobe Photoshop software (Adobe Systems Inc.).

\section{Quantification of OPN Immunolabeling}

At day 3, prior to cell confluence, OPN labeling was quantified under epifluorescence using $\times 40$ microscopic fields. The percentage of the substrate area occupied by OPN labeling (red fluorescence) was determined by analyzing the acquired digital images using Image Tool software (University of Texas Health Science Center; San Antonio, TX, USA).

\section{Statistical Analysis}

Comparisons were performed using nonparametric test for independent data (Kruskal-Wallis), followed by post-hoc test (Fisher's least significance difference multiple comparisons procedure) (16). The level of significance was set at $5 \%$. The results are representative of experiments performed with three distinct primary cultures.

\section{RESULTS}

High resolution SEM imaging showed a smooth surface at the nanoscale for the Control Ti, whereas a unique nanotopography characterized by a network of nanopits was conspicuously noticed for both treated Ti (Fig. 1). It was worth noting that the Nano(4h) Ti exhibited areas with larger nanopits compared with Nano(30') Ti, as judged qualitatively (Fig. 1, compare $\mathrm{C}$ with $\mathrm{B})$. For cultures grown on either Control Ti or Nano(30') Ti OPN labeling was mostly intracellular, in a perinuclear region indicative of the Golgi apparatus and in punctate deposits throughout the cytoplasm. In addition, no extracellular OPN labeling was detectable (Fig. 2). Conversely, on the Nano(4h) Ti, large extracellular OPN deposits were noticed adjacent to cells exhibiting typical intracellular labeling and morphology of migrating cells on two-dimensional substrates. Interestingly, BSP labeling at day 7 revealed similar findings (i.e., ECM tracks) for the Nano(30') Ti group (Fig. 2, compare F with B, arrowheads). At day 3, quantitative results in terms of OPN-labeled areas were as follows: Nano(4h) $\mathrm{Ti}>\mathrm{Nano}\left(30^{\prime}\right) \mathrm{Ti}>$ Control $\mathrm{Ti}$ (Kruskal-Wallis test, $\mathrm{p}<0.05$; Fig. 3).

\section{DISCUSSION}

The results of this in vitro study demonstrated that the early extracellular OPN accumulation in osteogenic cell cultures might be affected by nanotopographical Ti surface features. Indeed, significantly enhanced extracellular OPN deposits were noticed for cultures grown on Nano(4h) Ti but not on Nano(30') Ti or control $\mathrm{Ti}$, in a labeling pattern similar to those originally described elsewhere by our group $(16,17,22)$. The presence of larger nanopits for the Nano(4h) Ti surface is in agreement with previous studies showing that nanopore dimensions can be tuned by changing the etching time of Ti or other medically-relevant metals
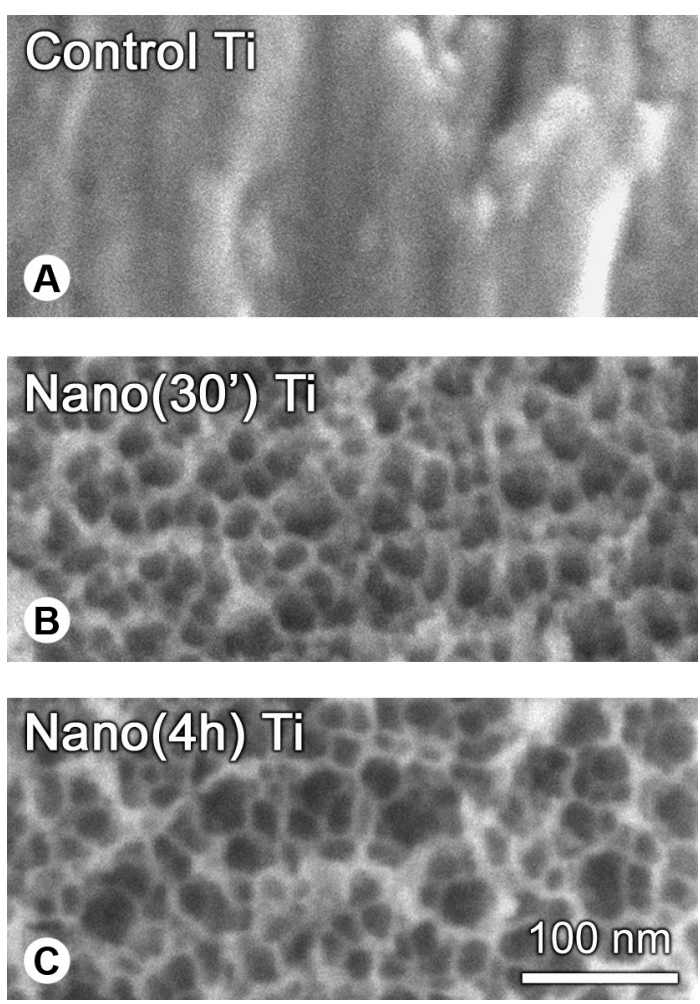

Figure 1. High resolution scanning electron micrographs of Ti surfaces. (A) The control, untreated surface appears smooth at the nanoscale. (B,C) Chemically treated Ti surfaces with $\mathrm{H}_{2} \mathrm{SO}_{4} / \mathrm{H}_{2} \mathrm{O}_{2}$ exhibit a unique nanotopography characterized by a network of nanopits. Areas with larger nanopits are noticed only for Nano(4h) Ti (compare C with B). Scale bar $=100 \mathrm{~nm}$. 

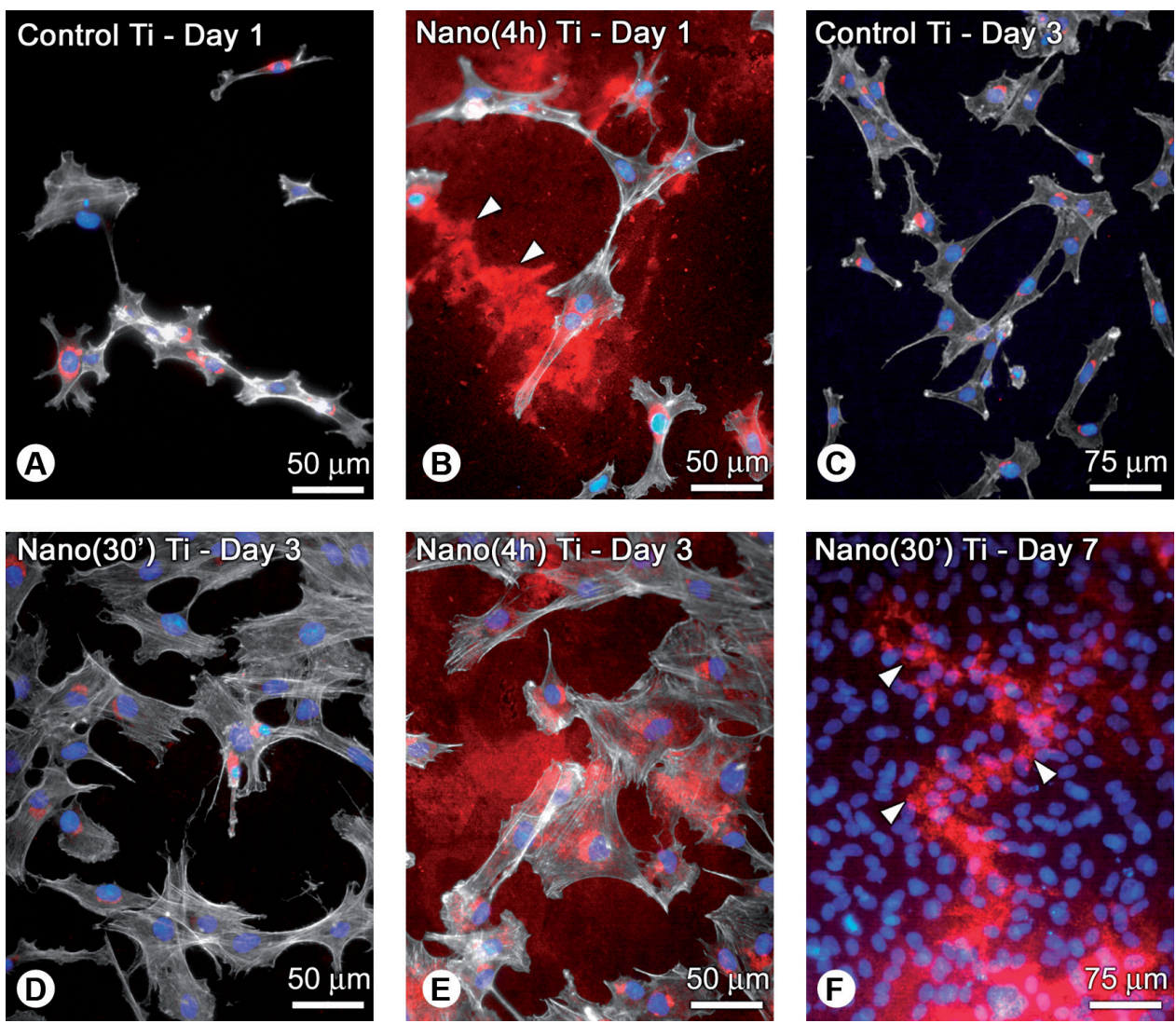

Figure 2. Triple-labeled fluorescence preparations of calvaria-derived osteogenic cell cultures grown on Control Ti (A,C), Nano(4h) Ti (B,E), and Nano(30') Ti (D,F) at days 1 (A,B), 3 (C-E), and 7 (F). A,C = Osteopontin (OPN) labeling (red fluorescence) on the control surface is mainly cytoplasmic, in a perinuclear region indicative of the Golgi apparatus and in punctate deposits. $\mathrm{B}, \mathrm{D}=\mathrm{On}$ the Nano(4h) Ti, large extracellular OPN aggregates are noticed adjacent to cells exhibiting typical cytoplasmic labeling and morphology of directional cell movement. $\mathrm{E}=$ No extracellular OPN labeling is detectable for Nano(30') Ti at day 3. F = At day 7, the extracellular BSP labeling on Nano(30') Ti resembles the tracks of OPN left behind by migrating cells at day 3 (compare F with B, arrowheads). Green fluorescence (Alexa Fluor 488-conjugated phalloidin) reveals actin cytoskeleton (whitish labeling for A-E), while blue fluorescence (DAPI DNA stain) highlights cell nuclei (A-F). Scale bars: A,B,D,E $=50 \mu \mathrm{m} ; \mathrm{C}, \mathrm{F}=75 \mu \mathrm{m}$.

\section{Osteopontin Immunolabeling}

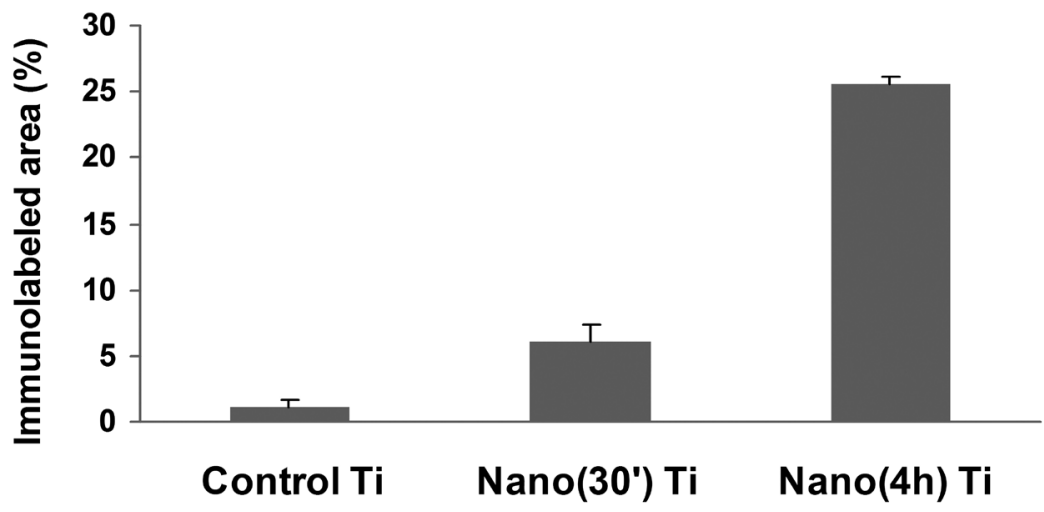

Figure 3. Quantification of osteopontin (OPN) immunolabeling at day 3 by image analysis (Image Tool software) revealed significantly larger OPN-positive areas for Nano(4h) Ti compared with either Nano(30’) Ti or Control Ti (Kruskal-Wallis test, p<0.05). Data are reported as mean $\pm \mathrm{SD}$. 
$(19,22)$. Importantly, changes in surface topographical features at the nanoscale (in the 1-100 $\mathrm{nm}$ range) have been demonstrated to affect protein adsorption, cell morphology and function of various cell types, including fibroblasts, osteoblasts, and macrophages (reviewed in $7,8,23)$.

In the present study, primary cells derived from newborn rat calvarial bone were chosen to evaluate the effect of Ti nanotopographies on the early OPN distribution since after 1 day in culture at least 50\% of such heterogeneous cell population, including pre-osteoblasts, differentiated osteoblasts, osteocytes, and fibroblasts, are immunoreactive for OPN (24). OPN labeling was quantitatively assessed at day 3, allowing the detection of extracellular OPN prior to cell confluence. Based on the statistical analysis of data, one could speculate that both Nano(30') Ti and Nano(4h) Ti support the up-regulation of OPN (16) but only the nanotopography obtained with the 4 h-etching could retain/adsorb more efficiently the secreted protein. However, it appears that Nano(30') Ti can also efficiently adsorb endogenous ECM proteins, as judged by the tracks of BSP left behind by migrating osteoblastic cells $(16,25)$ at day 7 . Ongoing quantitative studies in our lab are now focusing on the impact of diverse nanostructured Ti surface topographies on either the early OPN mRNA and protein expression or the osteogenic potential of primary cultures.

In conclusion, we showed that it is possible to control the endogenous extracellular accumulation of OPN at the Ti surface by tuning the nanoscale topographical features. Such finding is particularly important for the development of strategies aiming to functionalize biomaterial surfaces with molecules that are known to promote cell adhesion. The chemical nanostructuring needed to immobilize bioactive molecules may per se alter the relative proportions of plasma and ECM proteins that are expected to naturally coat the biomaterial surface during the early events of tissue healing adjacent to implants.

\section{RESUMO}

A interface osso-implante é caracterizada pela presença de uma camada de matriz extracellular (MEC) afibrilar rica em proteínas não-colágenas, incluindo osteopontina (OPN), cujas funções no tecido ósseo estão relacionadas à adesão celular e ao controle do processo de mineralização da MEC (crescimento de cristais). Aspectos físicos e químicos das superfícies de biomateriais podem afetar as interações célula-MEC-substrato. O objetivo do presente estudo foi demonstrar a capacidade de aspectos nanotopográficos de superfície de titânio (Ti) de controlar a deposição extracelular de OPN in vitro. Discos de Ti foram tratados quimicamente por solução de $\mathrm{H}_{2} \mathrm{SO}_{4} / \mathrm{H}_{2} \mathrm{O}_{2}$ durante 30 min [Nano(30') Ti] ou $4 \mathrm{~h}$ [Nano(4h) Ti]. Superfícies de Ti não tratadas foram usadas como controle. Células osteogênicas primárias derivadas de calvárias de ratos recém-nascidos foram plaqueadas sobre os discos de Ti e cultivadas em condições osteogênicas por até 7 dias. Microscopia eletrônica de varredura de alta resolução revelou que os discos de Ti tratados quimicamente exibiam superfície nanoporosa, com áreas de nanoporos maiores para Nano(4h) Ti. Apenas para esse grupo detectavam-se acúmulos extensos de OPN extracelular, os quais se distribuíam em áreas adjacentes a células OPN-positivas, com aspectos morfológicos típicos de células em migração. Em conclusão, a nanoestruturação química de superfície de Ti pode favorecer o aumento da deposição extracelular de OPN endógena por células osteogênicas in vitro, dependendo do tempo de condicionamento utilizado, o que deve ser considerado no desenvolvimento de estratégias para funcionalizar superfícies de implantes com moléculas com reconhecido efeito no processo de adesão celular.

\section{ACKNOWLEDGEMENTS}

This study was supported by The São Paulo State Research Foundation (FAPESP, Brazil). Antonio Nanci wishes to acknowledge support from the Canadian Institutes of Health Research (CIHR) and the Natural Sciences and Engineering Research Council of Canada (NSERC). The authors thank Roger Rodrigo Fernandes (University of São Paulo) for invaluable technical assistance, and Sylvia F. Zalzal (Université de Montréal) for high-resolution SEM imaging. Renan de Barros e Lima Bueno, Larissa Moreira Spinola de Castro-Raucci, and Patricia Adachi are recipients of Masters, Doctoral, and Post-Doctoral scholarships from FAPESP, respectively. The mouse monoclonal anti-rat osteopontin (MPIIIB10-1) and anti-rat bone sialoprotein (WVID1-9C5) antibodies, developed by Michael Solursh and Ahnders Franzen, were obtained from the Developmental Studies Hybridoma Bank formed under the auspices of the NICHD and maintained by The University of Iowa, Department of Biological Sciences (Iowa City, IA 52242).

\section{REFERENCES}

1. Kazanecki CC, Uzwiak DJ, Denhardt DT. Control of osteopontin signaling and function by post-translational phosphorylation and protein folding. J Cell Biochem 2007;102:912-924.

2. Denhardt DT, Noda M, O'Regan AW, Pavlin D, Berman JS. Osteopontin as a means to cope with environmental insults: regulation of inflammation, tissue remodeling, and cell survival. J Clin Invest 2001;107:1055-1061.

3. Sodek J, Ganss B, McKee MD. Osteopontin. Crit Rev Oral Biol Med 2000;11:279-303.

4. Franzén A, Hultenby K, Reinholt FP, Onnerfjord P, Heinegård D. Altered osteoclast development and function in osteopontin deficient mice. J Orthop Res 2008;26:721-728.

5. Standal T, Borset M, Sundan A. Role of osteopontin in adhesion, migration, cell survival and bone remodeling. Exp Oncol 2004;26:179-184.

6. McKee MD, Nanci A. Osteopontin at mineralized tissue interfaces in bone, teeth, and osseointegrated implants: ultrastructural 
distribution and implications for mineralized tissue formation, turnover and repair. Microsc Res Tech 1996;33:141-164.

7. Variola F, Brunski JB, Orsini G, Tambasco de Oliveira P, Wazen R, Nanci A. Nanoscale surface modifications of medically-relevant metals: state-of-the art and perspectives. Nanoscale 2011;3:335353.

8. Lord MS, Foss M, Besenbacher F. Influence of nanoscale surface topography on protein adsorption and cellular response. Nano Today 2010;5:66-78.

9. Garcia AJ, Reyes CD. Bio-adhesive surfaces to promote osteoblast differentiation and bone formation. J Dent Res 2005;84:407-413.

10. Beutner R, Michael J, Schwenzer B, Scharnweber D. Biological nano-functionalization of titanium-based biomaterial surfaces: a flexible toolbox. J R Soc Interface 2010;7:S93-S105.

11. Shekaran A, Garcia AJ. Nanoscale engineering of extracellular matrix-mimetic bioadhesive surfaces and implants for tissue engineering. Biochim Biophys Acta 2011;1810:350-360.

12. Bellis SL. Advantages of RGD peptides for directing cell association with biomaterials. Biomaterials 2011;32:4205-4210.

13. Malmström J, Christensen B, Lovmand J, Sørensen ES, Duch M, Sutherland DS. Osteopontin presentation affects cell adhesion Influence of underlying surface chemistry and nanopatterning of osteopontin. J Biomed Mater Res A 2010;95:518-530.

14. O'Toole GC, Salih E, Gallagher C, FitzPatrick D, O'Higgins N, O'Rourke SK. Bone sialoprotein-coated femoral implants are osteoinductive but mechanically compromised. J Orthop Res 2004;22:641-646.

15. Nanci A, Wuest JD, Peru L, Brunet P, Sharma V, Zalzal S, et al.. Chemical modification of titanium surfaces for covalent attachment of biological molecules. J Biomed Mater Res 1998;40:324-335.

16. De Oliveira PT, Nanci A. Nanotexturing of titanium-based surfaces upregulates expression of bone sialoprotein and osteopontin by cultured osteogenic cells. Biomaterials 2004;25:403-413.
17. De Oliveira PT, Zalzal SF, Beloti MM, Rosa AL, Nanci A Enhancement of in vitro osteogenesis on titanium by chemically produced nanotopography. J Biomed Mater Res A 2007;80:554564.

18. Richert L, Variola F, Rosei F, Wuest JD, Nanci A. Adsorption of proteins on nanoporous Ti surfaces. Surf Sci 2010;604:1445-1451.

19. Variola F, Lauria L, Nanci A, Rosei F. Influence of treatment conditions on the chemical oxidative activity of $\mathrm{H}_{2} \mathrm{SO}_{4} / \mathrm{H}_{2} \mathrm{O}_{2}$ mixtures for modulating the topography of titanium. Adv Eng Mater 2009;11:B227-B234.

20. Schwartz Fo HO, Novaes AB Jr, de Castro LM, Rosa AL, de Oliveira PT. In vitro osteogenesis on a microstructured titanium surface with additional submicron-scale topography. Clin Oral Implants Res 2007;18:333-344.

21. De Oliva MA, Maximiano WM, de Castro LM, da Silva PE Jr, Fernandes RR, Ciancaglini $\mathrm{P}$, et al.. Treatment with a growth factor-protein mixture inhibits formation of mineralized nodules in osteogenic cell cultures grown on titanium. J Histochem Cytochem 2009;57:265-276.

22. Vetrone F, Variola F, Tambasco de Oliveira P, Zalzal SF, Yi JH, Sam J, et al.. Nanoscale oxidative patterning of metallic surfaces to modulate cell activity and fate. Nano Lett 2009;9:659-665.

23. Novaes AB Jr, de Souza SL, de Barros RR, Pereira KK, Iezzi G, Piattelli A. Influence of implant surfaces on osseointegration. Braz Dent J 2010;21:471-481.

24. De Oliveira PT, Zalzal SF, Irie K, Nanci A. Early expression of bone matrix proteins in osteogenic cell cultures. J Histochem Cytochem 2003;51:633-641.

25. Halfter W, Liverani D, Vigny M, Monard D. Deposition of extracellular matrix along the pathways of migrating fibroblasts. Cell Tissue Res 1990;262:467-481.

Accepted April 5, 2011 